\title{
Comparative study of enzymes in testes and ovaries from adult Dipetalogaster maximus (Uhler) and Triatoma infestans (Klug) (Hemiptera: Reduviidae). Correlation with fine structural organization
}

\author{
P.Y. Scaraffia, C. Maldonado ${ }^{1}$, A. Aoki ${ }^{1}$, and N.M. Gerez De Burgos
}

Cátedra de Química Biológica and ' Centro de Microscopía Electrónica, Facultad de Ciencias Médicas, Universidad Nacional de Córdoba. 5016 Córdoba, Argentina

Accepted: 15/11/00

Key words: Dipetalogaster maximus, Triatoma infestans, enzymes, testes, ovaries, ultrastructure

\section{SUMMARY}

Activities of hexokinase (HK), glucose-6-phosphate dehydrogenase (G6PDH), fructose-6-phosphate kinase (F6PK), glutamate dehydrogenase (GlutDH), aspartate aminotransferase (AAT), malate dehydrogenase (MDH) and glycerol-3-phosphate dehydrogenase (GPDH) were determined in tissue extracts of testes and ovaries of adult Dipetalogaster maximus (Uhler) and Triatoma infestans (Klug) (Hemiptera: Reduviidae), insect vectors of Chagas disease. The fine structure organization of the same organs were studied by electron microscopy. Results allow the following inferences: in testes from both species, most of the glucose would be utilized through the glycolytic pathway. Amino acid catabolism for energy purposes appears to be unimportant. The number of mitochondria and the development of the rough endoplasmic reticulum in cells of the spermatogenic line indicate the occurrence of active oxidative metabolism and protein synthesis; in ovaries, levels of G6PDH indicate the existence of an active pentose pathway which would supply the NADPH required for fat and ecdysteroid synthesis. Amino acid catabolism appears to be relatively more important in ovary than in testis. Fat and glycogen are stored in follicular cells of D. maximus; oocytes of both species contain numerous fat droplets. Abundant mitocondria are present in follicular cells and oocytes. A well developed rough endoplasmic reticulum and free ribosomes are also conspicuous in these cells. The malate/aspartate H-transfer system seemed to be relatively more important than the glycerophosphate shuttle in ovaries as well in testes.

\section{INTRODUCTION}

Many members of the subfamily Triatominae are vectors of Trypanosoma cruzi, the etiological agent of American trypanosomiasis. This pathology, also known as Chagas' disease, is one of the most serious infectious disease in South America, with 17 million persons infected (Moncayo, 1993). Vectors of this disease are distributed throughout the American continent and some Caribbean islands, between latitudes $40^{\circ} \mathrm{N}$ and $56^{\circ} \mathrm{S}$ (Schofield, 1985).

Dipetalogaster maximus (Uhler), a sylvatic triatomine species which occupies mainly rocky habitats (Ryckman and Ryckman, 1967) is found in Mexico (Southernmost Baja California). Triatoma infestans (Klug) is the main vector of Cha- 
gas' disease throughout the southern half of South America. It is well known for its adaptation to domestic habitats (Lent and Wygodzinsky, 1979). Neither a reliable treatment for chronic chagasic patients nor a vaccine are available yet. So far, vector control is the most effective method to reduce the rate of infestation. The implementation of effective control methods requires a deep knowledge of the vector biology, biochemistry and physiology. We have recently studied enzymes involved in energy producing pathways of thoracic muscles of D. maximus and T. infestans in the latter stages of metamorphosis (Scaraffia et al., 1997).

Knowledge of functional aspects of the organs involved in reproduction of these species may be useful for the development of control procedures. We have determined the activity of several enzymes related to carbohydrate and amino acid metabolism and correlated them with ultrastructure of adult testes and ovaries. Results are reported in this paper.

\section{MATERIALS AND METHODS}

\section{Insects}

Adult males and females of $D$. maximus and $T$. infestans were obtained from the insectary of the Centro de Referencia de Vectores, Servicio Nacional de Chagas, Córdoba, Argentina. Colonies were maintained at $28^{\circ} \mathrm{C} \pm 1^{\circ} \mathrm{C}$, under a relative humidity of 60 to $70 \%$ and a photoperiod of 6 hs light: 18 hs dark. Insects were fed on live chickens once every 2 weeks after the imaginal ecdysis. Four days after the second feeding, testes and ovaries were dissected out. Each sample weighing about $300 \mathrm{mg}$ (wet weight) represented a pool of testes or ovaries. Tissue samples were homogenized in distilled water (1:5, W:V) using an Ultra-Turrax T 25 tissue disruptor. The tube with the preparation was placed in an ice bath during homogenization, which was performed in three 1 -min pulses at 15 -sec intervals. The suspensions were centrifuged at $20,000 \mathrm{~g}$ for $40 \mathrm{~min}\left(4^{\circ} \mathrm{C}\right)$ and the supernatants used for enzyme and protein determinations.

\section{Enzyme assays}

Hexokinase (HK, EC 2.7.1.1). We followed the method of Bergmeyer et al., (1974 a). The assay medium contained $45 \mathrm{mM}$ Tris- $\mathrm{HCl}$ buffer $\mathrm{pH} 7.6$, $185 \mathrm{mM}$ D-glucose, $7 \mathrm{mM} \mathrm{MgCl} 2,0.85 \mathrm{mM} \mathrm{NADP}^{+}$ (monosodium salt), $0.60 \mathrm{mM}$ ATP (disodium salt) and $0.65 \mathrm{U}$ glucose-6-phosphate dehydrogenase.

Fructose-6-phosphate kinase (F6PK, EC 2.7.1.11). An adaptation of the method of Bergmeyer et al., (1974 b) was utilized. The assay medium was: 70 $\mathrm{mM}$ Tris- $\mathrm{HCl}$ buffer $\mathrm{pH} 8.5,1.40 \mathrm{mM} \mathrm{MgSO}_{4}, 4.30$ $\mathrm{mM} \mathrm{KCl}, 1.60 \mathrm{mM}$ phosphoenol pyruvate (monosodium salt), $2.07 \mathrm{mM}$ fructose-6-P (disodium salt), $1.08 \mathrm{mM}$ ATP (disodium salt), $0.44 \mathrm{mM}$ NADH (disodium salt), $30 \mathrm{U}$ pyruvate kinase and 9.6 U lactate dehydrogenase.

Glucose-6-phosphate dehydrogenase (G6PDH, EC 1.1.1.49). The technique described by Löhr and Waller (1974) was used. The assay medium was composed of $40 \mathrm{mM}$ Tris- $\mathrm{HCl}$ buffer $\mathrm{pH}$ 7.6, $7 \mathrm{mM}$ $\mathrm{MgCl}_{2}, 1.10$ mM D-glucose-6-phosphate (disodium salt) and 0.82 mM NADP (monosodium salt).

Glutamate dehydrogenase (GIDH, EC 1.4.1.4). The method used by Cazzulo et al., (1977) was followed. The assay medium contained $40 \mathrm{mM}$ Tris- $\mathrm{HCl}$ buffer $\mathrm{pH} 7.6,100 \mathrm{mM} \mathrm{NH}_{4} \mathrm{Cl}, 0.90 \mathrm{mM}$ EDTA, $0.17 \mathrm{mM}$ NADH (disodium salt), $3 \mathrm{mM} \alpha-$ ketoglutaric acid (monosodium salt) and $1.40 \mathrm{mM}$ ADP (potassium salt)

Aspartate aminotransferase (AAT, EC 2.6.1.1). An adaptation of Bergmeyer and Bernt's method (1974) was utilized. The assay medium was 75 $\mathrm{mM}$ phosphate buffer $\mathrm{pH} 7.4,12 \mathrm{mM} \alpha$-ketoglutaric acid (monosodium salt), $50 \mathrm{mM}$ L-aspartic acid (monopotassium salt), $0.17 \mathrm{mM} \mathrm{NADH}$ (disodium salt) and $5 \mathrm{U}$ malate dehydrogenase.

Malate dehydrogenase (MDH, EC 1.1.1.37). The method of Yoshida (1969) was used. The assay mixture contained $100 \mathrm{mM}$ Tris- $\mathrm{HCl}$ buffer $\mathrm{pH}$ 8.8, $1 \mathrm{mM}$ oxalacetic acid and $0.17 \mathrm{mM} \mathrm{NADH}$ (disodium salt).

Glycerol-3-phosphate dehydrogenase (GPDH, EC 1.1.1.8). The technique described by Fink and Brosemer (1975) was followed. The assay medium was composed of $50 \mathrm{mM}$ MOPS buffer $\mathrm{pH}$ 6.6, $0.17 \mathrm{mM}$ NADH (disodium salt) and 0.20 $\mathrm{mM}$ dihydroxyacetone phosphate (lithium salt).

The final assay volume was $3 \mathrm{ml}$ for all enzymes, except for HK, GlutDH and GPDH, in which the final volume was $1 \mathrm{ml}$. Enzyme activities were determined in the supernatant by following the changes in absorbance at $340 \mathrm{~nm}$ in a Beckman DU 70 spectrophotometer with the cuvette compartment thermostabilized at $30^{\circ} \mathrm{C}$. In all the assays the reaction was started by addition of the enzyme 
preparation, diluted to give an absorbance change between 0.050 and 0.250 per min and absorbance was read every $10 \mathrm{sec}$ during $2 \mathrm{~min}$. One unit of enzyme is the amount that utilizes $1 \mu \mathrm{mol}$ of substrate per min in the assay conditions. The molar extinction coefficient of $6.22 \mathrm{~cm}^{2} / \mu \mathrm{mol}$ was used to calculate NADH oxidation or $\mathrm{NAD}^{+}$and $\mathrm{NADP}^{+}$ reduction. Activity is expressed as specific activity (U per mg protein) and U per g of wet tissue. Controls were performed in all determinations by omitting the substrate in the assay mixture. Values reported represent the mean \pm standard error of 10 determinations on different samples.

\section{Total Proteins}

The protein contents were determined following the procedure of Smith et al. (1985).

\section{Statistical analysis of data}

Data are presented as means \pm standard error of the mean. Significant differences between means were determined by the Student's t-test. Excel program was used to perform one way analysis of variance. Duncan's test was applied for multiple comparisons of the means.

\section{Electron microscopy}

Adult testes and ovaries were fixed for $24 \mathrm{~h}$ at $4^{\circ} \mathrm{C}$ by inmersion in a mixture of $4 \%$ glutaralde- hyde, $4 \%$ formaldehyde in $0.1 \mathrm{M}$ phosphate buffer, pH 7.2 (Karnovsky, 1965). After fixation, the tissues were dissected, washed briefly in distilled water and treated with $1 \%$ osmium tetroxide for $1 \mathrm{~h}$ at room temperature. After dehydration in a series of cold acetone solutions, the tissues were embedded in araldite and sliced with a Jeol Jum-7 ultramicrotome. Thin sections were mounted on naked 200 mesh copper grids, contrasted with uranyl acetate and lead citrate and examined in a Siemens Elmiskop 101 electron microscope.

\section{RESULTS}

In testes and ovaries from D. maximus and $T$. infestans the enzymes investigated showed no significant differences in activity between species, except for hexokinase (HK), which was lower in D. maximus (Tables I and II).

\section{Testes}

Activities of fructose-6-phosphate kinase (F6PK) in D. maximus and T. infestans, either expressed in $\mathrm{U} / \mathrm{mg}$ protein or $\mathrm{U} / \mathrm{g}$ wet tissue, were higher than that of glucose-6-phosphate dehydrogenase (G6PDH).

HK activity was lower than F6PK activity in $D$. maximus; in contrast, HK was higher than F6PK in T. infestans.

Table I

Enzyme activities of testes from Dipetalogaster maximus and Triatoma infestans

\begin{tabular}{|c|c|c|c|c|}
\hline \multirow{2}{*}{ Enzyme } & \multicolumn{2}{|c|}{ Dipetalogaster maximus } & \multicolumn{2}{|c|}{ Triatoma infestans } \\
\hline & U/g Tissue & U/mg Protein & U/g Tissue & U/mg Protein \\
\hline HK & $0.65 \pm 0.06 *$ & $0.02 \pm 0.001 *$ & $3.66 \pm 0.42$ & $0.07 \pm 0.008$ \\
\hline F6PK & $1.45 \pm 0.16 \mathrm{~ns}$ & $0.03 \pm 0.004 \mathrm{~ns}$ & $1.69 \pm 0.26$ & $0.03 \pm 0.005$ \\
\hline G6PDH & $0.37 \pm 0.05 \mathrm{~ns}$ & $0.01 \pm 0.001 \mathrm{~ns}$ & $0.46 \pm 0.17$ & $0.01 \pm 0.003$ \\
\hline GlutDH & $0.70 \pm 0.04 \mathrm{~ns}$ & $0.02 \pm 0.001 \mathrm{~ns}$ & $0.75 \pm 0.05$ & $0.02 \pm 0.001$ \\
\hline AAT & $3.14 \pm 0.18 \mathrm{~ns}$ & $0.07 \pm 0.004 \mathrm{~ns}$ & $3.39 \pm 0.49$ & $0.07 \pm 0.010$ \\
\hline MDH & $39.52 \pm 2.82 \mathrm{~ns}$ & $0.92 \pm 0.067 \mathrm{~ns}$ & $37.56 \pm 0.55$ & $0.75 \pm 0.011$ \\
\hline GPDH & $1.05 \pm 0.05 \mathrm{~ns}$ & $0.02 \pm 0.001 \mathrm{~ns}$ & $0.90 \pm 0.05$ & $0.02 \pm 0.001$ \\
\hline
\end{tabular}

Values represent means \pm S.E. of determinations on 10 different samples. Amounts of total soluble protein were: $42.73 \pm 1.11 \mathrm{mg} / \mathrm{g}$ of wet tissue in D. maximus and $50.37 \pm 1.73 \mathrm{mg} / \mathrm{g}$ of wet tissue in T. infestans. *Indicates significant difference with T. infestans; $\mathrm{p}<0.001$; ns: not significant with $T$. infestans (Student's test). In D. maximus F6PK activity is significantly different from HK, G6PDH and GlutDH ( $\mathrm{p}<0.01)$. In T. infestans F6PK activity is lower than HK activity but F6PK activity is higher than G6PDH and GlutDH activities ( $\mathrm{p}<0.01)$. In each species GPDH activity is lower than AAT and MDH activities ( $p<0.01)$. ANOVA and Duncan's test. 
Table II

Enzyme activities of ovaries from Dipetalogaster maximus and Triatoma infestans

\begin{tabular}{lrrrr}
\hline & \multicolumn{2}{c}{ Dipetalogaster maximus } & \multicolumn{2}{c}{ Triatoma infestans } \\
\cline { 2 - 6 } & \multicolumn{1}{c}{ U/g Tissue } & U/mg Protein & U/g Tissue & U/mg Protein \\
\hline HK & $0.95 \pm 0.08 *$ & $0.01 \pm 0.001 *$ & $1.95 \pm 0.06$ & $0.03 \pm 0.001$ \\
F6PK & $1.69 \pm 0.31 \mathrm{~ns}$ & $0.02 \pm 0.003 \mathrm{~ns}$ & $1.45 \pm 0.17$ & $0.02 \pm 0.003$ \\
G6PDH & $1.91 \pm 0.12 \mathrm{~ns}$ & $0.02 \pm 0.002 \mathrm{~ns}$ & $1.37 \pm 0.16$ & $0.02 \pm 0.002$ \\
GlutDH & $2.40 \pm 0.05 \mathrm{~ns}$ & $0.03 \pm 0.001 \mathrm{~ns}$ & $2.02 \pm 0.05$ & $0.03 \pm 0.001$ \\
AAT & $3.86 \pm 0.42 \mathrm{~ns}$ & $0.05 \pm 0.005 \mathrm{~ns}$ & $4.15 \pm 0.26$ & $0.06 \pm 0.004$ \\
MDH & $45.99 \pm 3.21 \mathrm{~ns}$ & $0.58 \pm 0.041 \mathrm{~ns}$ & $2.46 \pm 1.86$ & $0.48 \pm 0.029$ \\
GPDH & $2.76 \pm 0.30 \mathrm{~ns}$ & $0.04 \pm 0.004 \mathrm{~ns}$ & 0.04 & $0.04 \pm 0.001$ \\
\hline
\end{tabular}

Values represent means \pm S.E. of determinations on 10 different samples. Amounts of total soluble protein were: $78.97 \pm 2.10 \mathrm{mg} / \mathrm{g}$ of wet tissue in D. maximus and $65.21 \pm 1.84 \mathrm{mg} / \mathrm{g}$ of wet tissue in T. infestans. *Indicates significant difference with $T$. infestans; $\mathrm{p}<0.001$; ns: not significant difference with $T$. infestans (Student's test). In $D$. maximus HK activity is significantly lower than F6PK, G6PDH and GlutDH activities ( $\mathrm{p}<0.05)$. There are no significant differences between F6PK and G6PDH activities. In T. infestans F6PK activity is lower than HK and GlutDH activities ( $\mathrm{p}<0.05$ ). F6PK and G6PDH activities are not significantly different. In each species GPDH activity is lower than AAT and MDH activities ( $\mathrm{p}<0.01)$. ANOVA and Duncan's test.

The level of F6PK was twice as high as glutamate dehydrogenase (GlutDH) in both species.

Enzymes involved in the malate-aspartate system for hydrogen transfer to mitochondia (aspartate aminotransferase, AAT, and malate dehydrogenase, MDH) showed higher activity than glycerophosphate dehydrogenase (GPDH), which participates in the glycerophosphate shuttle (Table I).

\section{Ovaries}

Fructose-6-phosphate kinase showed similar activity to G6PDH. At variance with $T$. infestans, HK activity in D. maximus was lower than that for F6PK.

The level of GlutDH was higher than that for F6PK in both species. AAT and MDH activities were greater than that of GPDH (Table II).

\section{Protein}

Total soluble protein values, expressed in mg per $\mathrm{g}$ of wet tissue, were $42.73 \pm 1.11$ and $50.37 \pm 1.73$ for testes from D. maximus and T. infestans respectively (Table I). In ovaries the values were $78.97 \pm$ 2.10 in and $65.21 \pm 1.84$ for ovaries from $D$. maximus and T. infestans respectively (Table II).

\section{Electron microscopy}

Testes. In testes of D. maximus and T. infestans, the shape, size and distribution of mitochondria changed strikingly along the spermatogenic cell line (Figs. 1-4). In early stages of spermatocytes, mitochondria are small, oval or round (Fig. 1). In later stages, spermatocytes show increasing numbers of larger mitochondria which spread throughout the cytoplasm (Fig. 2). Besides, the spermatocytes exhibit abundant rough endoplasmic reticulum (RER) cisternae and typical Golgi complexes.

Spermatids present characteristic mitochondria clustered into a single large mitochondrion, or mitochondrial derivative (nebenkern) (Fig. 3). In this giant structure, the fusion of the mitochondrial subunits continues until two large interlocking

Figs. 1/4 - (1)Spermatocyte from D. maximus testes. Small mitochondria (M) are clustered in a perinuclear area. Nuclei contain big nucleolus $(\mathrm{Nu})$. X 10, 500. (2)Spermatocyte from T. infestans. Numerous predominantly oval mitochondria appear intermingled with RER cisternae and free ribosomes. GC: Golgi complex. X 10, 500. (3)Spermatid of T. infestans. A large mitochondrial derivate $(\mathrm{M})$ occurs in a paranuclear position. In the nucleus $(\mathrm{N})$, heterochromatin form a ring against the nuclear membrane. $\mathrm{X}$ 10, 500. (4)Late spermatid of D. maximus. Two separated elongated mitochondria (M) show a rich cristae development. X 10, 500 

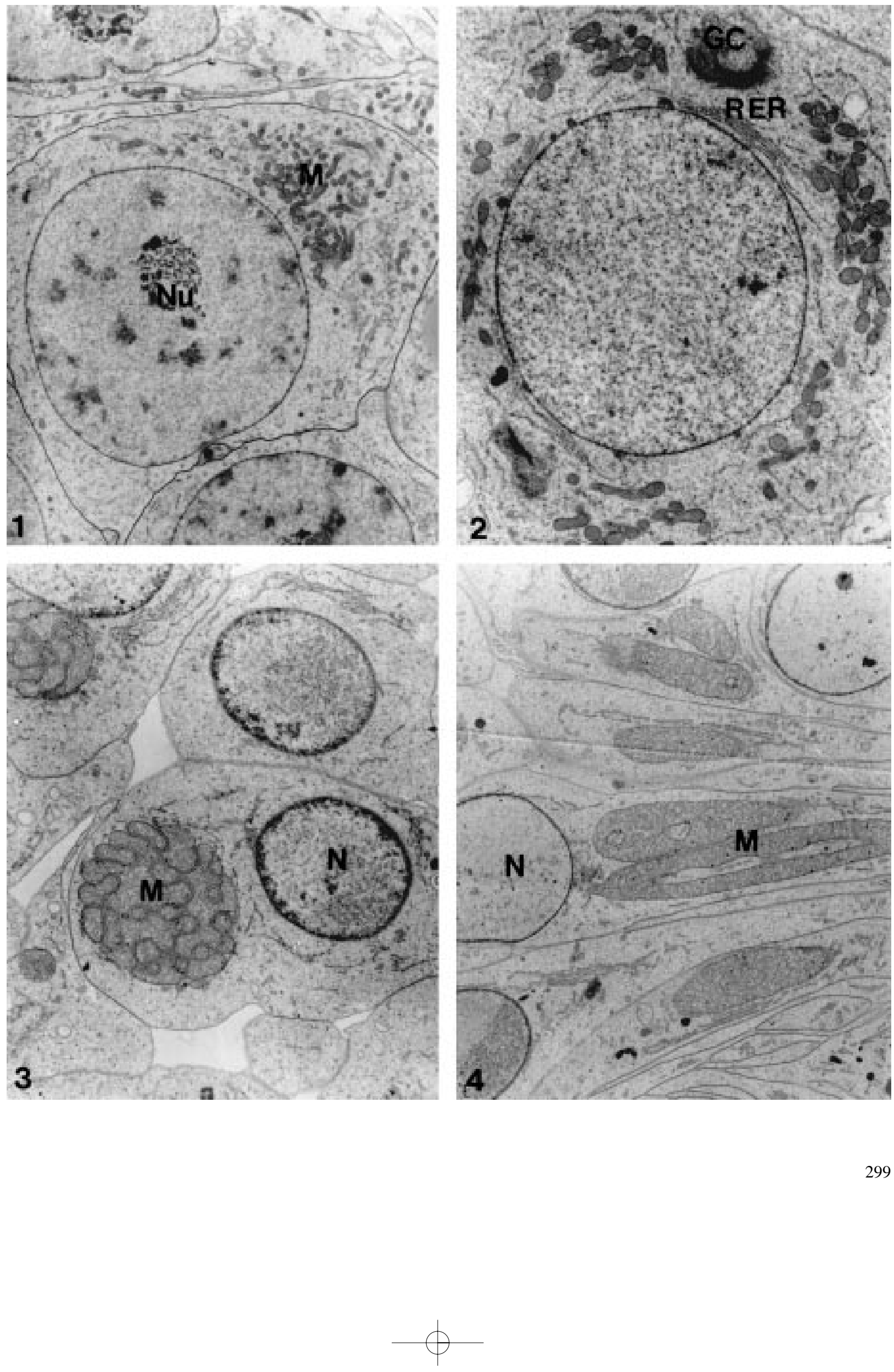
mitochondrial masses are formed (Fig. 4). In the next stage, the two interwoven nebenkern mitochondria start to elongate and stretch along the base of the future flagellum.

Ovaries. Follicular cells exhibit elongated mitochondria intermingled with abundant membranes of RER and free ribosomes (Fig. 5). Occasionally they may contain lipid droplets with associated glycogen particles (Fig. 6)

In oocytes from both species, mitochondria are long and slender and frequently associated with abundant lipid droplets (Fig. 7). Lipid content varies according to the oocyte stage. Abundant free ribosomes fill up the rest of the oocyte cytoplasm.

\section{DISCUSSION}

Observations at the ultrastructural level and determinations of enzyme activities of gonads from adult Dipetalogaster maximus and Triatoma infestans allow some inferences on the relative importance of different metabolic pathways operating in those organs.

In testes, ratios of activities of fructose-6-phosphate kinase over glucose-6-phosphate dehydrogenase (F6PK/G6PDH) would suggest that, in both species, a greater proportion of the glucose metabolized follows the glycolytic instead of the pentose pathway. The high level of hexokinase,
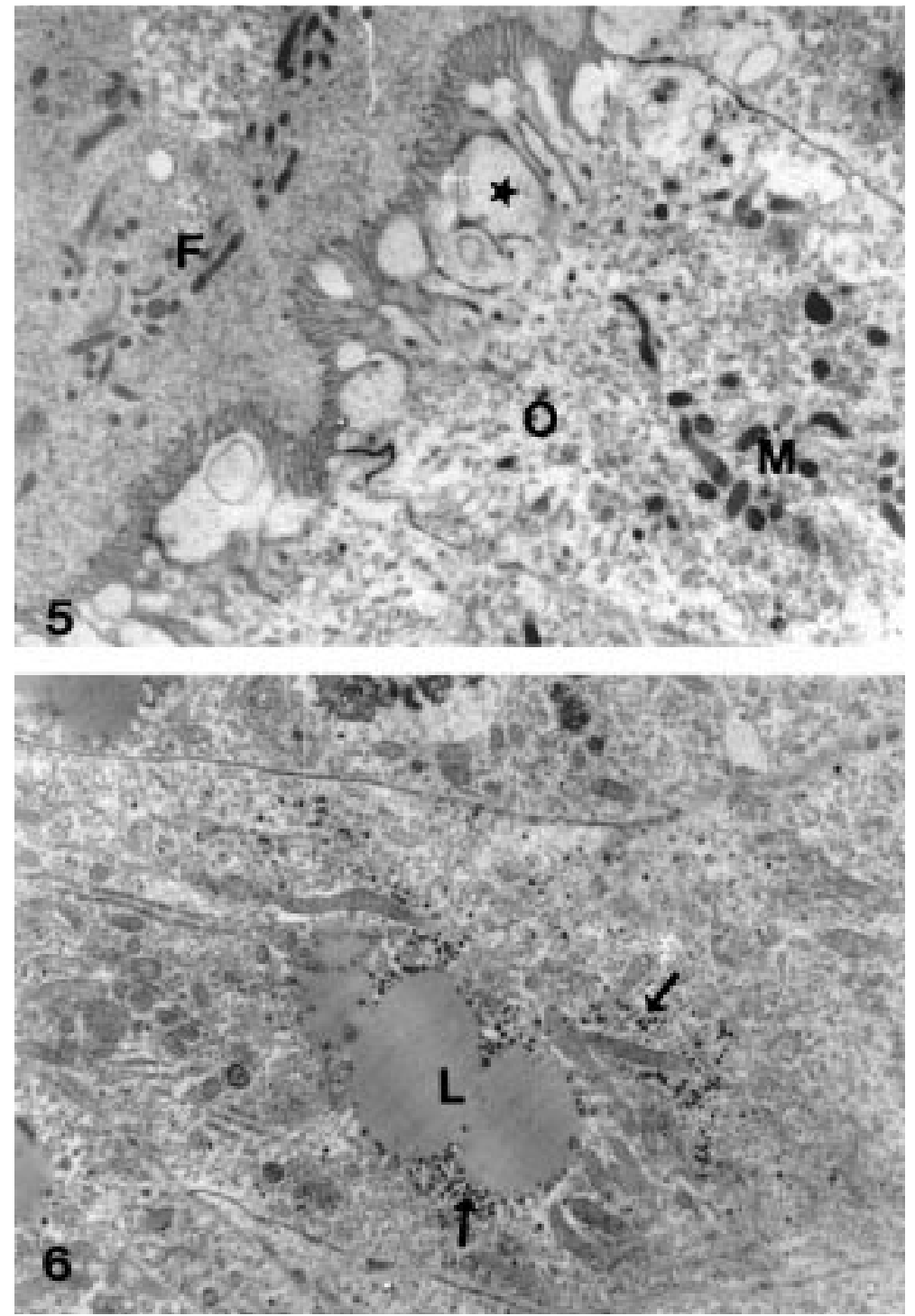

Figs. 5/6 - (5)Follicular cell (F) and oocytes (O) of $T$. infestans separated by interdigitation area $(*)$. Oocyte mitochondria $(\mathrm{M})$ are small and appear frequently in the periphery. $X$ 10,500. (6)Lipid droplets (L) associated with glycogen particles (arrowheads) are present in some follicular cells from D. maximus. $\mathrm{X} 10,500$. 


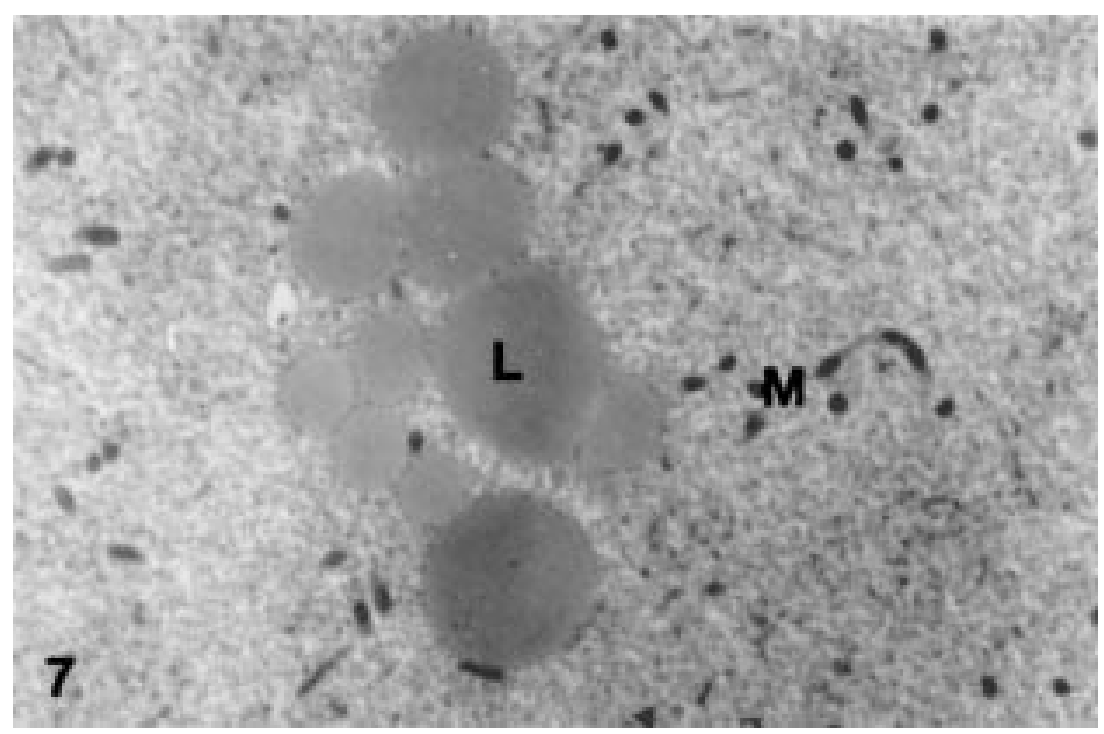

Fig. 7 - Oocyte of D. maximus ovaries containing abundant lipid droplets $(\mathrm{L})$ in contact with thin and elongated mitochondria (M). The remaining cytoplasm contains numerous ribosomes. X 10, 500 . specially in T. infestans, indicates that glucose supplied by the hemolymph would be a major fuel for testis rather than that produced by endogenous glycogenolysis.

In both species, values of glutamate dehydrogenase (GlutDH) would indicate that amino acid catabolism for energetic purposes appears to be unimportant. In contrast, flight muscles from the same insects show a much higher GlutDH activity: $1.61 \mathrm{U} / \mathrm{mg}$ for $D$. maximus and 0.87 for T. infestans (Scaraffia et al., 1997) suggesting a larger contribution of amino acid catabolism to the production of energy in muscles than in testes.

The abundance of mitochondria in cells of the spermatogenic line would reflect an intense respiratory activity. Changes in shape, size and distribution of these organelles are interesting. They are similar to those described by Phillips (1970) for other species. Particulary abundant are the mitochondria in spermatocytes, which are organized in large clusters. Up to now we have no clues on the functional significance of these mitochondrial rearrangements. Striking changes also occur in mitochondria of higher animals during sperm differentiation from spermatocytes up to the formation of the mitochondrial sheath of the mid-piece of spermatozoa (André, 1962). However, the highly structured mitochondrial clusters shown here are not observed in higher species.

Aspartate aminotransferase (AAT) and malate dehydrogenase $(\mathrm{MDH})$ activities compared to that of glycerophosphate dehydrogenase (GPDH) would indicate that the malate/aspartate shuttle would be more active than the glycerophosphate system for the transfer of reducing equivalents into the mitochondria.

Spermatocytes and spermatids of both species present a well developed rough endoplasmic reticulum and abundant free ribosomes, reflecting an important protein synthetic activity.

In ovaries, follicular cells of $D$. maximus exhibited prominent fat droplets surrounded by glycogen. Similar observations were reported by Lutz and Huebner (1982) in prefollicular cells of Rhodnius prolixus. It appears then, at variance with testis, that glycogen and fats represent significant fuel stores in the ovary. In D. maximus, the higher activity of F6PK compared with HK probably indicates a relatively larger use of glucose from glycogen degradation.

Activities of HK in ovary, as well as in testes of T. infestans are much higher than those for D. maximus. This difference cannot be explained with the available data. It would appear that the capacity to utilize free glucose is higher in the cells of $T$. infestans ovaries and testes than of D. maximus.

In both species, the ratios of activities F6PK/G6$\mathrm{PDH}$ for ovaries are much lower than those of testes, suggesting that an important proportion of the glucose utilized may be diverted to the pentose pathway, thereby providing the required NAPDH for the synthesis of fatty acids and ecdysteroids. 
The production of ecdysteroids in ovary has been reported for many species (Grieneisen, 1994). The site of ecdysteroid synthesis has been localized in follicular cells of telotrophic ovaries from Tenebrio molitor (Laverdure et al., 1977) and Rhodnius (Ruegg et al., 1981, 1982) and the follicular epithelium of Locusta migratoria y Nauphoeta cinerea (Goltzené et al., 1978; Zhu and Lanzrein, 1984).

In ovaries, the activity of GlutDH is higher than that in testes, indicating that the ovary would utilize amino acids as energy source to a larger degree than the testis.

Mitochondria are abundant in follicular cells and oocytes. The relative activities of aspartate aminotransferase and malate dehydrogenase with respect to GPDH in ovaries follow the same trend as in testes. This suggests that the malate/aspartate shuttle in ovaries as well as in testes would be more active than that of glycerophosphate, at variance with our finding in muscles from the same insects (Scaraffia et al., 1997).

It has been demonstrated that follicular cells play an important role in the synthesis of yolk components. Among these are glycoproteins, phospholipds and triacylglycerides (Wigglesworth, 1972). Applying cytochemical techniques, Verma et al. (1972) described the occurrence of fatty and compound yolk in oocytes of Aspongopus obscurus. They comprise unsaturated neutral fats synthesized in oocytes. The compound yolk (CY), constituted by carbohydrates, protein and RNA has a dual origen: CY1 is synthesized de novo in oocytes, while CY2 is produced by modifications of yolk precursor substances incorporated into the follicular epithelium by pinocytosis.

Our studies show that enzymes and structures involved in the synthesis of triacylglycerides, phospholipids and proteins are present in ovaries of D. maximus and T. infestans. The pentose pathway would be the NADPH provider; the GPDH producing glycerophosphate from phospho-dihydroxyacetone, would supply a precursor for phospholipids and triacylglycerides. The conspicuous rough endoplasmic reticulum and free ribosomes in follicular cells and oocytes reflect an active protein synthesis. There is a higher content of total soluble protein in ovaries than in testes.

Results reported here are the first study on the metabolic capabilities of reproductive organs of two vectors of Chagas disease. We hope that a bet- ter understanding of these insects' biochemistry will provide more rational bases for the design of control methods.

\section{ACKNOWLEDGEMENTS}

We thank Dr. Antonio Blanco for valuable suggestions and critical revision of this manuscript. Our thanks also to Biologists Delmi Canale and Raúl Stariolo for providing the insects used in our studies. This investigation received financial support from the Consejo de Investigaciones Científicas y Tecnológicas of Córdoba Province (CONICOR), the Consejo de Investigaciones Científicas y Técnicas (CONICET) and the Secretaría de Ciencia y Tecnología (SECyT) of the National University of Córdoba, Argentina. C.M., A. A and N.M. G de B. are career investigators of the CONICET, Argentina.

\section{REFERENCES}

André J.: Contribution a la connaissance du chondriome. Etude de ses modifications ultrastructurales pendant la spermatogenese. J. Ultrastruct. Res. Suppl. 3, 1-185, 1962.

Bergmeyer H.U., Gawehn K., and Grassl M.: Enzymes as Biochemical Reagents. In: Methods of Enzymatic Analysis, vol. 1. (Ed. Bergmeyer, H.U.), Academic Press Inc., New York, pp. 473-474, 1974a.

Bergmeyer H.U., Gawehn K., and Grassl M.: Enzymes as Biochemical Reagents. In: Methods of Enzymatic Analysis, vol. 1. (Ed. Bergmeyer, H.U.). Academic Press Inc., New York, pp. 451, 1974b.

Bergmeyer H.U., and Bernt E.: Glutamate-oxaloacetate transaminase. UV-assay, manual method. In: Methods of Enzymatic Analysis, vol. 2. (Ed. Bergmeyer, H.U.),. Academic Press Inc., New York, pp. 727-733, 1974.

Cazzulo J.J., Juan S.M., and Segura E.L.: Glutamate dehydrogenase and aspartate aminotransferase in Trypanosoma cruzi. Comp. Biochem. Physiol. 56B, 301-303, 1977.

Fink S.C., and Brosemer R.W.: Glycerol-3-phosphate dehydrogenase from the honey bee. In: Methods in Enzymology, vol. XLI. (Ed. Wood, W.A), Academic Press Inc., New York, pp. $240-245,1975$.

Goltzené F., Lagueux M., Charlet M., and Hoffmann J.A.: The follicle cell epithelium of maturing ovaries of Locusta migratoria: A new biosynthetic tissue for ecdysone. HoppeSeylers Z. Physiol. Chem. 359, 1427-1434, 1978.

Greneisen M.L.: Recent advances in our knowledge of ecdysteroid biosynthesis in insects and crustaceans. Insect Biochem. Molec. Biol. 24, 115-132, 1994

Karnovsky M. J.: A formaldehyde-glutaraldehyde fixative of high osmolality for use in electron microscopy. J. Cell Biol. 27, 137, 1965. 
Laverdure A.M., Laguex M, and Hoffmann, J.A.: Ecdysone et développement ovarien chez la femelle adulte de Tenebrio molitor. Bull. Soc. Zool. Fr. 102, 311, 1977.

Lent H., and Wygodzinsky P.: Revision of the Triatominae (Hemiptera, Reduviidae) and their significance as vectors of Chagas disease. Bull. Amer. Mus. Nat. Hist. 163, 125-520, 1979.

Löhr G.W., and Waller H.D.: Glucose-6-phosphate dehydrogenase. In: Methods of Enzymatic Analysis, vol. 2. (Ed. Bergmeyer, H.U.), Academic Press Inc., New York, pp. 636643, 1974.

Lutz D.A., and Huebner, E.: Development and cellular differentiation of an insect telotropic ovary (Rhodnius prolixus). Tissue \& Cell. 12, 733-794, 1980.

Moncayo, A.: Chagas disease. In: Tropical disease research. Progresss 1991-92. Eleventh programme Report of the UNDP/World Bank/WHO Special Programme for Research and Training Tropical Disease (TDR). World Health Organization. Geneva. 67-75, 1993.

Phillips D.M.: Insect sperm: their structure and morphogenesis. J. Cell. Biol. 44, 243-277, 1970.

Ruegg R.P., Kriger F.L, Davey K.G, and Steel C.G.H.: Ovarian ecdysone elicits release of a myotropic ovulation hormone in Rhodnius (Insecta: Hemiptera). Int. J. Invertebr. Reprod. 3, 357-361, 1981.

Ruegg R.P., Orchard I., and Davey K.G.: 20-Hydroxy-ecdysone as a modulator of electrical activity in neurosecretory cells of Rhodnius prolixus. J. Insect Physiol. 28, 243-248, 1982.

Ryckman R.E., and Ryckman J.V.: Epizootiology of Trypanosoma cruzi in south-western North America. Part X: the biosystematics of Dipetalogaster maximus in Mexico (Hemiptera:Reduviidae) (kinetoplastida:Trypanosomidae). J. Med. Entomol. 4, 180-188, 1967.

Scaraffia P.Y., Remedi M.S, Maldonado C., Aoki A., and Gerez de Burgos N.M.: Enzymatic and ultrastructural changes in thoracic muscles of triatomine insects during the last stages of metamorphosis. Com. Biochem. Physiol. 116 A, 173-179, 1997.

Schofield C.J.: Control of Chagas disease vectors. Brit. Med. Bull. 41, 187-194, 1985.

Smith P.K., Krohn R.I, Hermanson G.T, Mallia A.K, Gartner F.H, Provenzano M.D., Fujimoto E.K., Goeke N.M, Olson B.J., and Klenk D.C. Measurement of protein using bicinchoninic acid. Anal. Biochem. 150, 76-85, 1985.

Verma G.P., Sinha R.C., and Verma, B.P. Cytochemical studies on vitellogenesis in Aspongopus obscurus (Hemiptera: Pentatomidae). J. Insect Physiol. 25, 873-878, 1979.

Wigglesworth V.B.: The Principles of Insect Physiology, (Ed. Wigglesworth V.B.) Chapman and Hall, London, pp. 146-177, 1972

Yoshida A.: L-Malate dehydrogenase from Bacillus subtilis. In: Methods in Enzymology, vol. XIII, (Eds. Lowenstein, J.M.), Academic Press Inc., New York, pp. 141-145, 1969.
Zhu X., and Lanzrein B.: Distribution of free and conjugated ecdysteroids between follicle cell sheath and ooplasm in oocytes of the cockroach Nauphoeta cinerea. Experientia, 40, 496-498, 1984. 